\title{
PERCEPTION OF PERSONS WITH ATAXIA
}

\author{
LUBA JAKUBOWSKA \\ Department of Promotion of Health, Faculty of Health Sciences, \\ Wroclaw Medical University \\ Barta 5, 51-618 Wrocław, Poland \\ e-mail address: luba.jakubowska@umed.wroc.pl \\ MAGDALENA KAZIMIERSKA-ZAJĄC \\ Department of Disorders of the Nervous System, Faculty of Health Sciences, \\ Wroclaw Medical University \\ Barta 5, 51-618 Wrocław, Poland \\ e-mail address: magdalena.kazimierska-zajac@umed.wroc.pl \\ JOANNA ROSIŃCZUK \\ Department of Disorders of the Nervous System, Faculty of Health Sciences, \\ Wroclaw Medical University \\ Barta 5, 51-618 Wrocław, Poland \\ e-mail address: joanna.rosinczuk@umed.wroc.pl
}

\begin{abstract}
Aim. The aim of the paper is to present the reasons of the forming of erroneous, unfavourable perception of persons with spinocerebellar ataxia.

Concept. Spinocerebellar ataxias (SCA) are a group of degenerative disorders leading to damage of the cerebellum and its connections (Klockgether, \& Paulson, 2011). The following are distinguished among the neurological speech difficulties present in persons with SCA: dysphagia (difficulties with swallowing leading to problems with eating), speech disorders, and mental disorders. Each of these groups of disorders may lead to the stigmatisation of persons with SCA. Such persons might be seen as sloppy and helpless, and the specificity of speech impairments and uncoordinated movements as well as their irregular gait may cause these persons to be perceived as inebriated. Such presumptions lead to difficulties in social functioning and may be the cause of discrimination, including the denial of help.

Conclusion: What is helpful in combating prejudice is, first and foremost, the dissemination of knowledge about the condition, including launching social campaigns presenting the labelled symptoms of SCA. What is more, work with the patient ought to be focused on the development of coping strategies in the social environment rather than exclusively alleviating physical difficulties.

Key words: Spinocerebellar ataxias (SCA), self-presentation, perception of persons with ataxia, image, neurological speech disorders
\end{abstract}


Perception of other people is predominantly an automatic process. On the basis of a minute amount of information an individual is able to form judgements of personality traits (Wojciszke, 2014; Borkenau, Liebler, 1992) and interpersonal attractiveness. In situations of uncertainty, with a sense of threat (which frequently arises from lack of knowledge and stereotypes) an individual may be prone to forming unfavourable judgements of a distinctly different person.

The aim of the paper is to present the reasons of the forming of the erroneous, unfavourable perception of persons with spinocerebellar ataxia.

\section{SPINOCEREBELLAR ATAXIAS - DESCRIPTION}

Spinocerebellar ataxias are a group of degenerative disorders leading to damage to the cerebellum and its connections (Klockgether, Paulson, 2011).

In a majority of individuals the disorder is manifested through impaired balance, ataxia, and impaired movement (Globas, du Montcel, Baliko, et al., 2008). The gait resembles that of an inebriated individual; it is uncoordinated and irregular and may lead to a fall. Impairments in gross motor skills are present in fine motor skills, as well. Improper functioning of speech organs produces the characteristic speech impairments. The disorder progresses leading to increasing impairments in motor and communication skills and, ultimately, to severe disability, complete dependence on third persons, anarthria, and dysphagia (impaired swallowing). It can develop in young adults as well as seniors. However, the onset of the symptoms are typically observed in the fourth decade of an individual's life (Sobczyk, Piłkowska, Sułek, Niewiadomska, Rakowicz, Poniatowska, Ryterski, Pałka, Goszczańska - Ciuchta, 2005).

The disorder is inherited in an autosomatically dominant way, which means that it is passed down to children by a parent suffering from the disorder, and there is a $50 \%$ probability of inheriting the disorder. In Poland the most common types of SCA are SCA1 and SCA2. The expansion of repetitions of CAG (the glutamine coding codon) influences the forming of the symptoms and the rate of the progress of SCA. What is characteristic for both types is the onset of disorder in adulthood, its progress, survival time of 10 to 30 years, lack of periods of re-emission, symptoms dependent on the number of repetitions of CAG, negative correlation between the number of repetitions and the age of the onset of symptoms, anticipation (the number of repetitions is not stable and increases from generation to generation), unchanged expression of the gene, increased severity of the disorder in subsequent generations, and intranuclear inclusions in neurons in the affected structures of the nervous system (Durr, 2010; Stevanin, Durr, Brice, 2000).

\section{NEUROLOGICAL SPEECH IMPAIRMENTS AND THE PERCEPTION OF PERSONS WITH SCA}

Among the greatest neurological impairments of persons with SCA one can distinguish dysphagia, speech disorders, and mental disorders. Let us have a 
look at each of the groups of disorders from the perspective of the forming of a favourable image.

\section{Dysphagia}

The group of disorders termed dysphagia describes the difficulties which persons with SCA experience when consuming meals.

The process of eating, which we are accustomed to treating as a biological function, belongs also to self-presentation techniques (serving to control the impression that one makes on other people) (Leary, 2007). The manner of consuming meals (e.g. the lack of hurry), the amount (e.g. refusing another serving) (Leary, 2007), cultural customs: (e.g. holding cutlery) (Wojciszke, 2014), waiting for others at the table to receive their orders in a restaurant; expressions connected with the ritual of eating (e.g. "Enjoy your meal"); maintaining body weight - all of these can be connected with the wish to produce a favourable impression.

Persons with spinocerebellar ataxia experience increasing eating difficulties with the progress of the disorder. Frequently they choke on fluids, fluids run out of the corners of their mouths or nostrils while drinking, With time they might choke on saliva (Kazimierska-Zając, Rosińczuk-Tonderys, 2011).

Such views may seem unsightly because the patients dirty themselves with food more often than others. What is more, they may be perceived as not independent because difficulties with using cutlery, choking, lack of movement coordination lead to them requiring the help of others.

Patients with ataxia experience eating problems, as well. Food appears to be blocked, patients choke and cough when they swallow. Because of the inability to swallow saliva it can run out along with the food, which can also attract the attention of observers.

A severe complication in impaired swallowing is the aspiration of chyme into the respiratory tract which leads to aspiration pneumonia (Czernuszenko, 2016).

The above problems constitute significant obstacles in social functioning of persons with ataxia, pertaining to integration as well as perception. Most family celebrations, going out to celebrate or for entertainment are connected with eating, and at the same time, social exposure, which persons with SCA may fear.

In the case of persons with ataxia changes in eating habits ought to be introduced pertaining to pace of eating and the type and consistency of food (Czernuszenko, 2016). The work is necessary first of all in order to prevent some of the eating difficulties from arising, but it also contributes to the emotional comfort of such people.

\section{Speech disorders}

Yet another group of disorders of persons with SCA is connected with speech.

It is the area in which it is easiest to misjudge persons with ataxia. The eating difficulties described above might invoke aversion in observers but mostly they result in the discomfort of individuals with SCA. They will, nevertheless, be predominantly perceived as symptoms of illness or bad physical 
shape. The speech impairment typical of ataxia, however, might be interpreted as the results of alcohol abuse or being under the influence of other psychoactive drugs. Such interpretation is particularly hurtful to individuals with the disorder because it forces them into the boundaries of one of the most unfavourable stereotypes, discouraging people from establishing any relations or even providing help.

The speech impairment present in spinocerebellar ataxia is the ataxic dysarthria. On the level of the motor execution of the mechanism of speech one can observe dysfunctions of the respiratory, phonatory, and articulative systems resulting in distortions of phonic substance in the segmental and suprasegmental plain. The impairments are caused by damage in the central and peripheral nervous systems.

In the process of the production of sounds of speech, as well as in gross motor skills, difficulties arise in fluency and movement coordination. In order to speak it is necessary for the respiratory, phonatory, and articulatory systems to cooperate. As a result of damage to the cerebellum speech becomes inarticulate and staccato. Similarly to other disorders in which the cerebellum is damaged, impairments to the rhythm of breathing are present also in SCA. The breath is shallow, the exhalation phase is shortened, the pace of speech is reduced (Schalling, Hartelius, 2004). Temporarily increases in pace of speech appear (Jauer-Niworowska, Kwasiborska, 2009). The patients prolong sounds and repeat them. The phonatory problem pertains to the shakiness and the huskiness of voice. One can clearly see that patients experience problems with speaking, severe tiredness is visible. Because of the discoordination of the muscles of articulation organs sounds are distorted and it is frequently impossible to understand the speech at all. In such cases alternative communication is required.

Inarticulateness, reduced pace, repetition of sounds become part of the script defining a person under the influence of alcohol. Such opinions may be exacerbated by the difficulties with balancing their bodies which patients with SCA experience, as well as their unsteady gait with a broadened base. Difficulties with moving are particularly hurtful because a person might be labelled even before initiating communication.

A number of psychological experiments show how dangerous such an interpretation may be when, e.g., a person lying on the street is not helped because passers-by think he/she is under the influence of alcohol.

\section{Mental disorders}

When describing accompanying disorders in SCA researchers draw attention to severe depressive disorders which frequently develop in spinocerebellar ataxia (McMurtray, Clark, Flood, et al, 2006).

Persons with ataxia may experience emotional discomfort in numerous areas. One of them is sleep. On the basis of an analysis of sleep in SCA2 it has been found that among the various sleep disorders the following appear more frequently in the group of patients with SCA2 than in the control group: insomnia ( 7 cases in 23 patients; 1 case in control group) and the restless legs 
syndrome (8 cases, 1 in control group) (Boesch, Frauscher, Brandauer, et al., 2006).

While this problem has no direct impact on social functioning it may lead to general reduction in concentration, irritability, etc.

In patients with cerebellar lesions one can observe certain affective and cognitive disorders. The patients experience difficulties with recognising emotions in facial expressions, which leads to their impeded recognition of social emotions (D'Agata, Caroppo, Baudino, et al., 2011). Cognitive disorders arise with various frequencies, depending on the type of SCA. And so dementia is observed more frequently in SCA1 than in SCA2 (Burk, Globas, Bosch, et al., 1999; Maruff, Tyler, Burt, et al., 1996). Research into cognitive disorders in patients with SCA1 which has been systematically conducted with the use of neuropsychological tools has revealed moderate mental handicap in single cases and disorders of verbal and executive memory with retainment of visual-spatial memory and concentration. Cognitive deficits tend to be the result of damage to a number of anatomical structures rather than lesions in a single area (Burk, Bosch, Globas, et al., 2001). These observations support the hypothesis that the cerebellum is important in motor activities as well as cognition.

The above symptoms can be treated as signs of mental handicap which is exceptionally negatively stereotyped relative to other disabilities (Mazurkiewicz, Oleksy 2012; cf. Wolińska, 2015; Sękowski, Witkowski, 2004).

Furthermore, difficulties with recognising emotions or impairments in verbal memory (in connection with the group of speech impairments described above) intensify communication problems experienced by persons with SCA which can also lead to the forming of negative impressions.

It ought to be noted that the levels of the impairment of cognitive skills in patients with SCA vary (Sokolovskya, Cookb, Hunta, Giuntib Cipolottia, 2010) which is why it is difficult to clearly distinguish the significance of the disorders of this type to the created impression.

\section{SUMMARY}

Interpretation of the behaviour of others according to the theories of attribution can be conducted through thorough analysis taking into account diverse factors (systematic bottom-up analysis) or by employing ready templates, considering only certain factors (top-down, heuristic analysis) (Lachowicz-Tabaczek, 2004).

Knowledge about ataxia may prevent the forming of unfavourable opinions even in the case of the top-down scheme of interpreting data.

Persons with ataxia are characterised by, first and foremost, three groups of disorders: dysphagia, speech disorders, and mental disorders. Each of these disorders can distinguish individuals with disorders according to the "Stigma" theory which is based on two elements: perceived difference founded in a certain characteristic trait, or a "peculiarity", and the resulting devaluation of the person bearing the peculiarity (Heatherton, Kleck, Hebl, Hull, 2008, p. 25). 
Stigma need not be connected with negative feelings towards an individual (Heatherton, Kleck, Hebl, Hull, 2008), e.g., apart from fear sympathy or willingness to help may appear. This ambivalent approach can even lead to the stigmatised persons being treated more favourably than those who do not bear a stigma (Heatherton, Kleck, Hebl, Hull, 2008).

The difficulties of persons with ataxia lie not in the symptoms of the disorder but their erroneous perception, e.g. treating speech impairments as signs of excessive alcohol use, or problems with eating as sloppiness.

The difficulties can result in a vicious circle - persons worried about the impression which they are making may be reluctant to appear in public places, and the lack of persons with ataxia in the social space decreases the level of knowledge about them. Social campaigns presenting the symptoms of ataxia in comparison with their stereotypical labelling ought to be initiated.

The way in which disorders are defined and perceived is formed by knowledge about them as well as cultural norms (Cierpiałkowska, 2014). Children ought to be accustomed with symptoms of various disorders and introduced to patterns of non-discriminatory and prosocial behaviour in the course of their socialisation.

The behaviour of an individual in accordance with an attitude depends on numerous factors, nevertheless, an attitude has to be available, because it is only then that one can talk about perception according to an attitude, or, what is more important, behaviour (Russell, Fazio, Carol, Williams, 2002).

What is frequently encountered becomes known, which results in reduced fear and forming of a more positive attitude (cf. Zajonc). Persons with disorders can combat stereotypes, as well, first and foremost by appearing in social space and revealing knowledge about themselves.

\section{REFERENCES}

1. Boesch S. M., Frauscher B., Brandauer E., et al. (2006). Disturbance of Rapid Eye Movement Sleep in Spinocerebellar Ataxia Type 2. Mov Disord, 21(10), 1751-1754.

2. Borkenau, P., Liebler, A., (1992). Trait in Sources of validity at zero acquaintance. Journal of Personality and Social Psychology, 31, 567-573

3. Burk K., Bosch S., Globas C., et al. (2001). Executive Dysfunction in Spinocerebellar Ataxia Type 1. Eur Neurol, 46, 43-48.

4. Burk K., Globas C., Bosch S., et al., (1999). Cognitive deficits in spinocerebellar ataxia 2 (SCA2). Brain, 122, 769-777.

5. Cierpiałkowska, L.,(2014). Psychopatologia [Psychopatology] Łódź: Scholar: 2014.

6. Czernuszenko, A. (2016). Postępowanie w dysfagii neurogennej [Procedure in neurogenic dysphagia], Otolaryngologia, 15(2), 68-74

7. D'Agata F., Caroppo P., Baudino B., et al., (2011). The Recognition of Facial Emotions in Spinocerebellar Ataxia Patients. Cerebellum, 10, 600-610.

8. Durr A., (2010). Autosomal dominant cerebellar ataxias: polyglutamine expansions and beyond. Lancet Neurol, 9, 885-894.

9. Globas Ch., du Montcel S.T., Baliko L., et al.: (2008). Early Symptoms in Spionocerebellar Ataxia Type 1, 2, 3, and 6. Mov Disord, 23(15), 2232-2238.

10. Heatherton, T.F., Kleck, R.E., M. R. Hebl, J.G. Hull (2008). Spoteczna psychologia piętna [Social psychology of stigma], Warszawa: PWN 
11. Jauer-Niworowska, O., Kwasiborska, J. (2009). Dyzartria. Wskazówki do diagnozy różnicowej poszczególnych typów dyzartrii [Dysarthria. Guidelines to differential diagnosis of the particular types of dysarthria]. Gliwice: Komlogo.

12. Kazimierska-Zając M., Rosińczuk-Tonderys J. (2011). Zaburzenia mowy w ataksji rdzeniowo-móżdżkowej jako wyzwanie dla logopedy [Speech disorders in spinocerebellar ataxia as a challenge to speech therapists]. In: A. Pozowski, S. Jarząb (eds.). Wybrane aspekty rehabilitacji [Selected aspects of rehabilitation]. Wrocław: Katedra Fizjoterapii. Akademia Medyczna im. Piastów Śląskich we Wrocławiu.

13. Klockgether T., Paulson H. (2011). Milestones in ataxia. Mov Disord 2011, 26, 1134-1141.

14. Lachowicz-Tabaczek K., (2004). Potoczne koncepcja świata i natury ludzkiej [Popular conceptions of the world and human nature]. Gdańsk: GWP.

15. Leary, M. (2007). Wywieranie wrażenia na innych. O sztuce autoprezentacji [Making impression on others. On the art of self-presentation]. Gdańsk: GWP.

16. Maruff P., Tyler P., Burt T., et al. (1996). Cognitive deficis in Machado-Joseph disease. Ann Neurol, 40, 421-427.

17. Mazurkiewicz B., Oleksy A. (2012). Problemy psychologiczne zwiazane z niepetnosprawnościa [Psychological problems connected with disability]. In: B. Mazurkiewicz, E. Dmoch-Gajzlerska (ed.), Opieka położnicza nad pacjentkami niepetnosprawnymi [Obstetric care of patients with disabilities], (pp.14-28).Warszawa: PZWL.

18. McMurtray A. M., Clark D. G., Flood M. K., et al. (2006). Depressieve and Memory Symptoms as Presenting Features of Spinocerebellar Ataxia. J Neuropsychiatry Clin Neurosci, 18, 420-422.

19. Russell, Fazio, Carol, Williams (2002). Dostępność postaw jako czynnik pośredniczący w zależności między postawami a spostrzeganiem i postawami a zachowaniem. Badania nad wyborami z $1984 \mathrm{r}$ [Availability of attitudes as a mediating factor between attitudes and perception and attitudes and behaviour. Research of choices of 1984]. In: E., Aronson (ed.) Człowiek jako istota spoteczna. Wybór tekstów [Man as a social entity. Selection of papers] (pp.230-254). PWN: Warszawa.

20. Schalling E., Hartelius L. (2004). Acoustic Analysis of Speech Tasks Performed by Three Individuals with Spinocerebellar Ataxia. Folia Phoniatr Logop 56, 367-380.

21. Sękowski, A. E., Witkowska, B. (2004). Psychologiczna analiza postaw pracowników domów pomocy społecznej wobec mieszkańców z zaburzeniami psychicznymi [Psychological analysis of the attitudes of the staff of nursing homes towards residents with metal disorders], Roczniki Psychologiczne, t. VII, (1). 57-75

22. Sobczyk W., Piłkowska E., Sułek A., Niewiadomska M., Rakowicz M., Poniatowska R., Ryterski J., Pałka Ł., Goszczańska - Ciuchta A. (2005). Przewlekłe zespoły móżdżkowe [Chronic cerebellar disorders]. Postępy psychiatrii i neurologii, 14(1), 11-18.

23. Sokolovskya, N., Cookb, A., Hunta, H., Giuntib, P., Cipolottia, L., (2010). A preliminary characterisation of cognition and social cognition in spinocerebellar ataxia types 2, 1, and 7, Behavioural Neurology 23, 17-29

24. Stevanin G., Durr A., Brice A. (2000). Clinical and molecuar advances in autosomal dominant cerebellar ataxias: from genotype to phenotype and physiopathology. Eur. J. Hum. Genet, 8, $4-18$.

25. Wojciszke, B. Psychologia Społeczna [Social psychology]. (2014), Scholar: Łódź.

26. Wolińska, J. (2015). Percepcja społeczna, stereotyp niepełnosprawności -perspektywa aktora i obserwatora [Social perception, stereotype of disability - perspective of the actor and the observer]. Annales Universitatis Mariae Curie-Skłodowska. Lublin-Polonia. VOL. XXVIII, 1, 45-66.

27. Zajonc. R.B., (1968). Attitudinal effects of mere exposure. "Journal of Personality and Social Psychology", 9 (2). 1-27 1968. 